\title{
Introduction: Development Challenges in Myanmar: Political Development and Politics of Development Intertwined
}

\section{Elin Bjarnegård ${ }^{1}$}

Published online: 17 March 2020

(C) The Author(s) 2020

\begin{abstract}
Myanmar faces enormous development challenges in the midst of a rapidly changing and uncertain landscape both in terms of politics and international aid. This article probes into the intertwined nature of political development and the politics of development, drawing upon existing literature and contributions of this special issue. It critically analyzes the mismatch between the long-term societal change processes that Myanmar faces, on the one hand, and the instability of domestic politics and international development, on the other. It is argued that the prospects for development in Myanmar need to be assessed in a context of constant interaction between political development and the politics of development.
\end{abstract}

Keywords Myanmar · Development · Politics · Aid · Democracy · Political development $\cdot$ Politics of development

\section{Résumé}

Le Myanmar s'affronte à des énormes défis de développement parmi un panorama politique et d'aide international très incertain et qui change très vite. Cet article sonde la nature étroitement mêlée des développements politiques et des politiques du développement, s'appuyant sur la littérature existante et sur les contributions incluses dans cette édition spéciale. On analyse de façon critique le décalage entre, d'un côté, les processus à longue durée d'adaptation sociale qui affronte le Myanmar ; et de l'autre côté, l'instabilité des politiques domestiques et du développement internationale. On soutient que les perspectives de développement au Myanmar doivent être évalués dans le contexte de l'interaction pérenne entre le développement politique et la politique du développement.

Elin Bjarnegård

Elin.Bjarnegard@statsvet.uu.se

1 Uppsala University, Uppsala, Sweden 


\section{Introduction}

Myanmar $^{1}$ faces enormous and multifaceted contemporary challenges. A third of Myanmar's 50-million population lives in poverty, the majority in rural areas. The country battles malnutrition, high infant mortality, and discrimination against women and girls. The Rohingya crisis caught the world's attention in 2017, when hundreds of thousands fled the country following what is described as ethnic cleansing. Many Rohingya are still in Myanmar but internally displaced in Rakhine State (see Fig. 1 for a map of Myanmar) and living under difficult circumstances. Myanmar is pursuing a nationwide peace process in the midst of ongoing armed conflict among different ethnic groups. The peace-building process is fragile: peace talks have not been inclusive, and some ethnic groups have not signed the peace agreement. These challenges constitute lived realities for many people, but the recent political changes in the country have been accompanied by a large influx of international aid. Both these developments-political development and the politics of development - seem to hold the promise that the multifaceted challenges can be better addressed. This article lays out the argument that the political development and the politics of international development in Myanmar are intrinsically connected and intertwined and that their unison impact needs to be understood in relation to the various particular development challenges that the country faces.

Development in itself is an essentially contested concept, and it is impossible to establish consensus about what it is and should be (Coetzee and Söderbaum 2016; Scholte and Söderbaum 2017). Focusing on the smallest common denominator of different definitions, it is possible to at least agree that development, according to the Cambridge Dictionary, constitutes a "process in which [...] something grows or changes and becomes more advanced." Because it is intrinsically difficult to define development, this article takes a broad view of the concept, referring to strategies to overcome a multitude of societal injustices based on poverty, ethnicity, gender, or other contextual vulnerabilities. Such a broad view of development is in line with a focus on human development (Sen 1999). It also goes hand in hand with the 2030 Agenda and the Sustainable Development Goals (SDGs), launched by the United Nations (UN) in 2015.

The political sphere is undergoing a process of change in Myanmar. With a long history of state repression, the democratization process is, however, fragile and uneven, despite a successful turnover by the National League for Democracy (NLD) and its symbolic leader Aung San Suu Kyi, following the 2015 elections. A relatively free, fair, and peaceful election may have been a prerequisite for continued democratic development, but it is far from a guarantee. The NLD government needs to undertake political and economic reforms, but it needs to do so while dealing with the military legacy and the continued influence of the armed forces. It must also allow space for the strengthening of other political parties and of civil society.

\footnotetext{
1 Myanmar is often called Burma, and there is a debate regarding the meaning of the name of the country (Bünte 2009). In this issue, the country's official name since 1989 is used: Myanmar.
} 
As a result of the political liberalization in Myanmar since 2011, the influx of donor funds and the presence of aid organizations have multiplied. Development challenges in Myanmar are thus also of a practical nature; there is a need to strike a balance between external expertise and local involvement and knowledge, to improve coordination of activities and programs of different organizations, and to balance the development industry's call for efficiency through results-based management with long-term commitment to tackling complex societal problems. Collaboration between donors and the Myanmar government is seen as necessary to improve state capacity and stability needed to implement wide-reaching reforms, but it also poses risks for peace. The strengthening of the state without similar engagement with ethnic actors and civil society can highlight the uneven power dynamics that are drivers of conflict.

These development challenges require in-depth understanding and expertise; yet they are complex and intertwined and cannot be tackled one by one. By studying a variety of development challenges in one and the same country, however, this special issue is able to combine thorough analyses with discussions about the interconnectedness of different themes, sectors, and actors. It uses two concepts as points of departure: political development and the politics of development. Through a deeper understanding of these concepts, it is possible to begin to define and understand the environment in which these development challenges are taking place. The concepts are broad enough to travel to contexts outside of Myanmar, and it is suggested that a shared understanding of political development as well as of the politics of development is a useful starting point for academic inquiry as well as for practical development work.

This special issue brings together scholars and experts on political and economic development, ethnic conflict, gender inequality, and the impact of aid, all focusing on Myanmar but from a variety of disciplinary perspectives. As a whole, the issue seeks to explore empirical examples of how Myanmar is overcoming some challenges while others remain. In particular, all contributions focus on how the political changes in Myanmar have impacted either the conditions for development per se or aid dynamics and donor strategies. Some contributions also shed light on how the politics of development affect the political development of the country. This focus on the intertwined nature of political development and the politics of development has a broad relevance, although its various manifestations are here studied through the lens of Myanmar.

\section{Political Development and the Politics of Development}

Political development is intertwined with the politics of development. The way in which a country is governed affects conditions for development as well as aid priorities and donor strategies in a multitude of ways. Democracy promotion is a central theme underpinning many of the projects and activities that the international development community implements in transitioning contexts, seeking to directly influence government priorities as well as the strength of domestic civil society actors. Government statements seemingly going in a new, more democratic, direction 


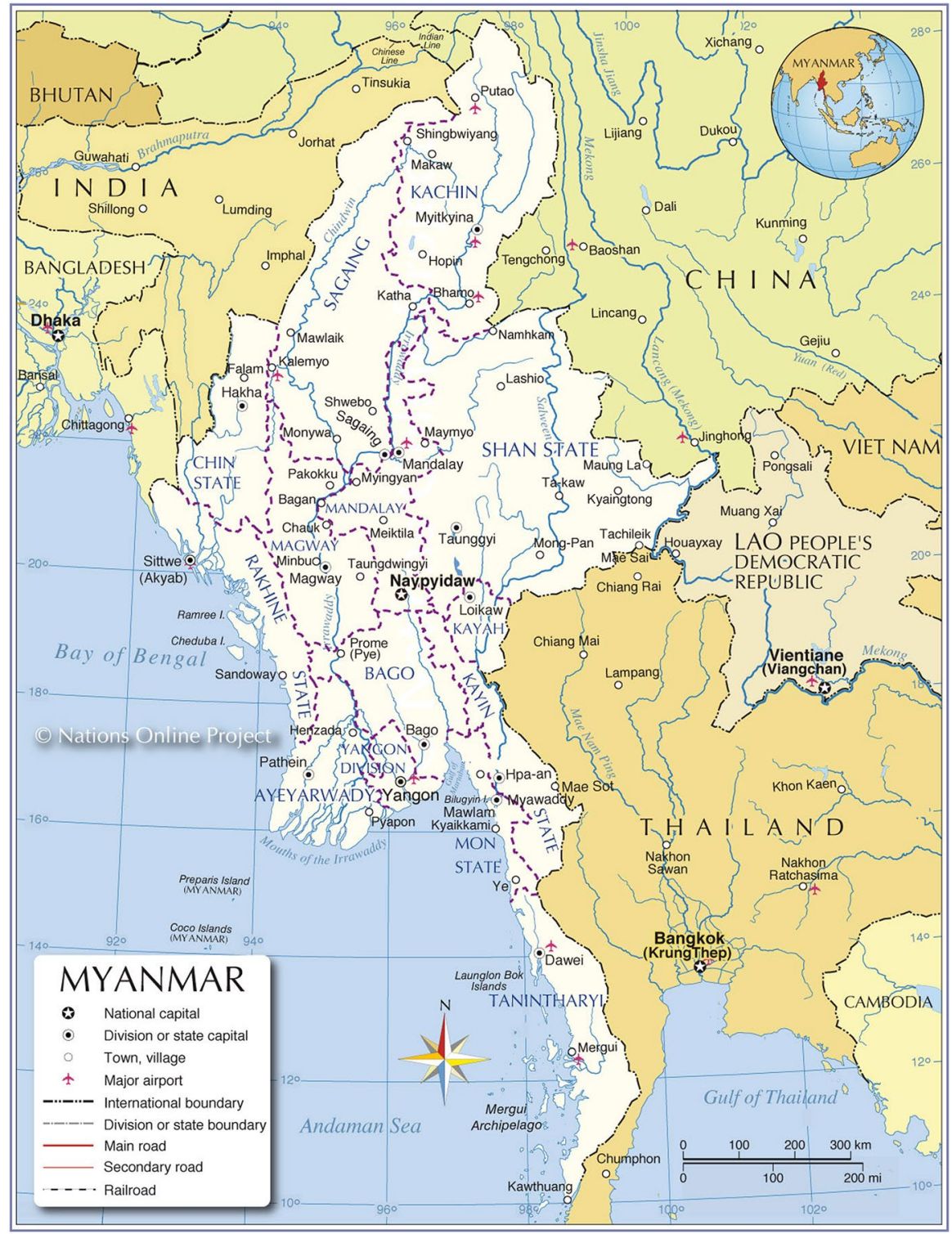

Fig. 1 Map of Myanmar. Source: One World-Nations Online and I downloaded the map from https:// www.nationsonline.org/oneworld/maps.htm

should thus be critically assessed against the demands of development actors, and shifting priorities of the development community must, in turn, be seen in the light of their understanding of the prospects for political change. Focusing on this interaction between powerful actors such as governments and development organizations is 
important for better understanding the lived realities of the people who face and live with the different development challenges on a daily basis.

In the past few decades, international development has been increasingly governed by performance indicators, seeking to report and measure progress according to set goals and templates. With the Millenium Development Goals (MDGs), adopted in 2001, such performance monitoring became a central instrument for international development actors (Fukuda-Parr et al. 2014; Skagerlind 2019). The SDGs were adopted by all UN member states in 2015, succeeded the MDGs, and have guided development actors and their priorities in the past few years. In comparison with the MDGs, the SDGs put stronger emphasis on the multifaceted and complex nature of development (Harcourt 2005; Fukuda-Parr 2016). One example is Goal 5, on gender equality, where gender equality is itself defined as a multidimensional process, incorporating a variety of issues such as unpaid work, economic opportunities, legal discrimination, sexual and reproductive health and rights, technology, empowerment, and gender-based violence. Importantly, it is not restricted to Goal 5, but gender issues are also brought up in relation to other goals (Fukuda-Parr 2016).

Another example of new view of development reflected in the SDGs is the emphasis on the fact that many of the most pressing development issues today are global in character - such as migration and climate, to name but two-and that they require international solutions and collaboration. This is underlined in that the SDGs call on all countries, not just the countries of the Global South, to work towards sustainability (Scholte and Söderbaum 2017; Fukuda-Parr 2016). The global responsibility is perceived as an important shift from the MDGs, which were mostly relevant for developing countries (Fukuda-Parr 2016). However, as Bexell and Jönsson (2017) argue, the responsibility for implementing the SDGs still leaves large leeway for nation-states to adapt them to domestic circumstances. There are also calls for stronger accountability mechanisms to avoid selectivity in implementation (Razavi 2016). This means that the willingness and capacity of nation-states are still of large importance for sustainable development.

In this context, focusing on the interaction between political development and the politics of development, it is noteworthy that the SDGs, despite their emphasis on the multifaceted nature of development, fail to mention the word "democracy" and that the concept of "human rights" is only mentioned once (Smith 2018). Regardless of the view taken on development, societal processes of change are strongly linked to national-level politics in general and are dependent on the space the state leaves for different actors to contribute. Political parties, women, ethnic minorities, nongovernmental organizations (NGOs), international organizations, and donor agencies are all potentially marginalized actors whose participation and influence are affected by state policies. If given space and voice, however, they may be in a position to affect development.

The lack of mention of democracy in the SDGs does not mean that democracy is not central to development work in practice. Western donor agencies and organizations often give politically conditional aid and engage in democracy promotion once a transition is deemed to be underway. Democracy aid is, in fact, increasing and gaining in importance (Scott and Steele 2011), although there are contradictory 
trends with a simultaneous increased influence of non-Western and nondemocratic actors on the international development arena (Carothers 2006). Most research demonstrates a positive relationship between democracy aid and democratization (Finkel et al. 2007; Scott and Steele 2011; Wright 2009), but there are limitations to the type of political development that donors support. According to Brown (2005), the preferred form of political change, from a donor perspective, takes place under controlled forms so that stability can be ensured. Mass demonstrations, political violence, and other radical, rapid, and potentially disruptive types of reform are seen as threatening to donor interests. Brown cautions that this focus on stability may sometimes come at the expense of progressive change. A large part of aid goes through the recipient government, but in the case of democracy aid, in particular, the majority of aid actually goes to nonstate actors (Scott and Steele 2011). Savun and Tirone (2011) demonstrate that democratizing states that receive external democracy assistance are less likely to experience violence and civil conflict than countries who do not receive such aid.

The recipients of democracy aid are also critically assessed in the literature, which increasingly questions whether democracy support leads to real change or merely to reluctant compliance and superficial reforms. Where the recipients are governments, they may offer official policy commitments, but not necessarily implementation (Skagerlind 2019). Even when NGOs are the beneficiaries, it needs to be remembered that they are increasingly professionalized and have their own survival instincts, implying they may seek out what Bush (2015) labels tamer types of democracy aid, not directly confronting the regime.

The role of the "development industry" is probably as debated as the concept of development itself. It has been claimed that development cooperation in practice is not as much of an equal partnership as dominant development discourses would have it (Eriksson Baaz 2005). Although development projects often fail to meet their targets, they still create a need for their own continuation. Ferguson (1990) argues that the development industry is a form of antipolitics machine, expanding bureaucracy while creating a development discourse presupposing a continued demand for generic technical solutions that are not always grounded in a historical or political understanding of the context. Neoliberal approaches to project management and the increasing use of global performance indicators mentioned above have become commonplace in development cooperation, and even long-term issues that are inherently difficult to measure, such as democratization and peace building, have become subjects to result-based management. Ideals of neutrality and efficiency are put forward in relation to sensitive issues where historical experiences or ideological convictions may lead to bias (Mac Ginty 2012).

The interaction between political development, on the one hand, and the logics of the development industry, on the other, are crucial for understanding contemporary Myanmar. To many, the implications of the recent political changes in Myanmar are not yet clear. The question is, as Stokke and Myint Aung (2020, in this special issue) put it, whether the political changes should be described as a "transition to democracy or hybrid regime?". This is, indeed, the question that development actors in Myanmar have asked themselves in what Décobert and Wells (2020, in this special issue) label their most recent "interpretive crisis." 
Décobert and Wells (2020, in this special issue) seek to "get into the heads" of the donor community to understand how donor representatives interpret the political context and how this affects their strategies towards aid in Myanmar. They claim that donors, by necessity, need to rely on simplifications to determine who should be perceived as a legitimate actor or a likely agent of change. The figure of Aung San Suu Kyi shaped this narrative for a long time, with her being a strong fairy-talelike symbol of democracy. The interpretive crisis, evident as the escalation of violence in Rakhine State received international attention, occurred as the gap between the dominant narrative and reality became too wide to ignore (Décobert and Wells 2020 , in this special issue).

Because donors have been forced to reinterpret their definitions of who constitutes a legitimate partner, they have also failed to work persistently and coherently with relevant actors, be it the Myanmar State or nonstate actors. Priorities regarding partners as well as program aims have shifted as a consequence of donors' interpretive crisis, not necessarily reflecting any real change on the part of the state or civil society. For instance, the attention to the violence in Rakhine State in 2017 seems to have led to a decrease in funding initiatives supporting the NLD, thus indirectly affecting the power balance between political actors and potentially the long-term political development (Décobert and Wells 2020, in this special issue).

The fact that the donor community experienced an interpretive crisis, suddenly questioning whether Myanmar was really en route to democracy, seems to have been, at least in part, a realistic awakening. Stokke and Myint Aung (2020, in this special issue) conclude that political development in Myanmar has led to what can be characterized as a hybrid form of rule rather than to democracy. The transition itself was imposed rather than negotiated, leaving ample continued political space for the military and creating a difficult position for the new government. The uneven, or patchy, democratization process along with the interpretive crisis of donors calls our attention to the complexity of development and the contradictory but tempting simplifications that are common as part of a democratization narrative (Décobert and Wells 2020, in this special issue). Political development in contemporary Myanmar opens up for continued interpretive complexity as new democratic spaces continue to coexist alongside weak popular representation and limited civilian control of the army (Stokke and Myint Aung 2020, in this special issue).

\section{Political Development in Myanmar}

This special issue should be read against the backdrop of the recent political changes in Myanmar. There was, at the same time, great hope and great concern ahead of the national elections in Myanmar in 2015. Despite strong signals of liberalization, observers feared that they were merely witnessing a new strategy for the military to ensure its survival (Croissant and Kamerling 2013; Huang 2013). The entire liberalization process was a top-down affair, orchestrated and controlled by the military regime and implemented in a gradual manner (Slater 2014; Bächtold 2015; Egreteau 2016; Stokke and Myint Aung 2020, in this special issue).The government reform rhetoric had not changed its often violent repression of ethnic groups and disrespect 
for human rights in ethnic minority areas, such as Kachin State (Seng Maw Lahpai 2014). There were also concerns that the electoral competition itself would spur violent clashes based on existing cleavages, such as religion and ethnicity (Nilsen and Tønnesson 2014). Myanmar emerged from a long history of military rule and repression of the opposition and has violent experiences from previous experiments with elections, where election results have subsequently been blatantly ignored. Thus, international presence was strong during the election period, with over 1000 international election observers complementing the 11,445 domestic observers (The Carter Center 2015, p. 67; EU EOM 2015, p. 23).

After the election itself, election observers concluded that the incumbent Union Solidarity and Development Party (USDP) had not only resigned and accepted the landslide victory of the then-opposition party NLD, but that the elections had also been relatively free, fair, and peaceful (Thawnghmung 2016). The Carter Center report confirmed that "Myanmar appears to be on a positive trajectory toward a peaceful, democratic transition as a result of these elections" (Carter Center, p. 5). An election that is relatively free, fair, and peaceful, resulting in a political turnover is certainly a significant event and arguably a prerequisite for continued democratization-but it is only the starting point and certainly no guarantee (Slater 2014). While transitional periods can constitute windows of opportunity for inclusion of a number of previously excluded groups, the persistence of traditional norms and influences is commonplace. In fact, consistent and predictable democratic consolidation tends to be the rare exception, while a partial reversal to some form of authoritarianism is the rule (Diamond 2002; Schedler 2006; Hadenius and Teorell 2007; Farrelly and Win 2016).

It has also been questioned whether the election was, in fact, "fair." A large number of potential voters were disenfranchised (Stokke et al. 2015). The military, while no longer officially in power, still yields considerable influence over politics as well as over internal security. The Constitution ensures that 25 percent of the seats are reserved for members of the military (Croissant and Kamerling 2013) and, instead of civilian control over the army, there is a continued need for power sharing between the NLD and the military, invoking definitions of Myanmar as a "disciplined democracy" (Slater 2014; Jones 2014a; Huang 2017). The development and institutionalization of political parties and civil society organizations are also necessary for democratic development and consolidation. Research suggests that political parties in Myanmar are not yet the effective and strong organizations they need to be to support representative democracy (Stokke et al. 2015).

Several reports also point to the hurdles that are still left for women in Myanmar politics in general and in party politics in particular (GEN 2017; Latt et al. 2017; Carothers 2016). While there are increasing initiatives to support young women activists, research suggests that workshops and training sessions for women may be inadequate in light of the social norms and traditional institutions they face (cf. Geha 2019). In a country where traditional leadership builds largely on age and sex, the awareness-raising process must go beyond focusing on women and aim for long-term transformation of institutions (Agatha Ma et al. 2018). The development needs of women, such as issues pertaining to the feminization of poverty, structural inequalities, discrimination, and violence are often not seen as political and 
societal issues (Ma Khin Mar Mar Kyi 2014; Hedström and Olivius 2020, in this special issue).

Just like the democratization process, the ongoing peace process between the state and the ethnic minority-based armed groups in Myanmar constitutes a potential promise but is also imbued with serious challenges. Myanmar experiences a rise in Buddhist ethnonationalism, which influences not just ethnic relations but also reinforces traditional patriarchal attitudes to women's social position (Barrow 2015; Hedström 2016; Htun and Jensenius 2020, in this special issue). The struggle between ethnic groups demanding increased autonomy on one side and the state, including the Tatmadaw (the Burma Army), on the other has been long, widespread, and violent. Almost all ethnic groups of Myanmar have, at one point or another since independence in 1948, fought for some degree of independence (Bünte 2009). Despite a peace process that was initiated in 2011, the persistence of nationalist Burmese views is evident also in the new Myanmar government. The case of the Rohingya is perhaps the most well-known example. The Rohingya is seen as excluded from the "national races" (Cheesman 2017). The role of the state in relation to groups living within its boundaries is important to future development and state building, but leaders' responses have been inconsistent and evasive, speaking about the need for rule of law, security, and keeping peace in the area. Aung San Suu Kyi has described the problem in terms of inefficient policing and lack of the security sector reform rather than in terms of lack of protection of human rights (Cheesman 2014). Representation of ethnic parties in politics is also low, following the 2015 election (Tan and Preece 2020, this special issue).

Women have been severely affected by the ongoing conflict and by violence (Hedström and Olivius 2020, this special issue). There are numerous documented reports of state-sponsored institutionalized sexual violence against women in ethnic minority communities. There has been little attention to these crimes in the peace process, and impunity seems to be the rule (WLB 2014). Although women have mobilized for influence in the peace process, for instance, through the Alliance for Gender Inclusion in the Peace Process (AGIPP), they and the issues they seek to raise have been marginalized (Hedström 2013, 2016; Bjarnegård 2017).

Kramer (2015) argues that, to be efficient, the peace talks must do more than establishing ceasefires; they must tackle the root causes by establishing an inclusive political dialogue. The diversity of Myanmar in terms of ethnicity and ecology also means that different systems of land tenure and use have developed over time (SiuSue Mark 2016). Along with displacements due to war and development exploitation, land conflict is one of the most pressing political issues, and intimately connected to the various conflicts and prospects for peace (Faxon et al. 2015). The development of a National Land Use Policy (NLUP) was an attempt to centralize and harmonize the question of land into one legal framework. In 2014, the government initiated a consultation process for input to the draft NLUP, but it has been criticized for not having enough involvement of ethnic groups while opening up for land grabbing (Kramer 2015). The NLUP was adopted in January 2015 and is described as a living document that provides principles for recognizing customary land rights, including women in land governance and acknowledging the rights of 


\section{ODA}

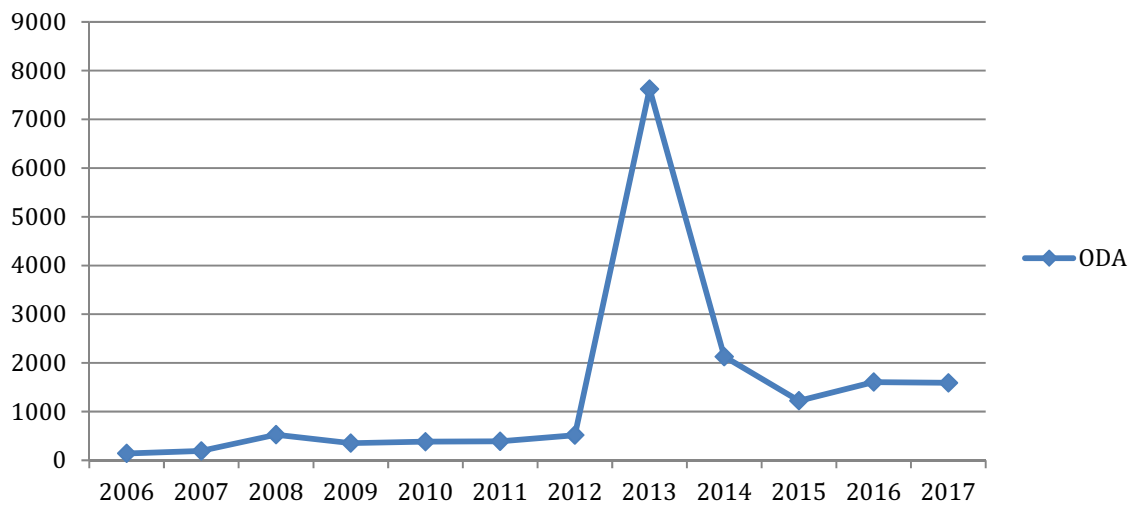

Fig. 2 Official development assistance to Myanmar 2006-2017. Source: Official Development Assistance (bilateral aid and multilateral concessional outflows), OECD-DAC

ethnic minorities (Hirschi 2018). The implementation and impact of this policy are yet to be assessed.

Hybrid governance is often used to describe the state of politics at the central level as well as in areas of limited statehood in Myanmar. At the national level, a civilian elected government needs to tread carefully so as to share power with the military. In areas of limited statehood, the ethnic armed organizations control of the area overlap with central government authority (South 2018; Stokke and Myint Aung 2020, this special issue). The characteristics of such a hybrid government and its capacity to tackle the many challenges that Myanmar is facing-including poverty, ethnic conflict, gender inequalities, and an ongoing crisis of refugees and internal displacement—-will be explored more in-depth in the articles of this issue.

\section{Politics of Development in Myanmar}

The interlinkages between the political promises and pitfalls, on the one hand, and the dynamics of the politics of development, on the other, are many. During the 1990s and the 2000s the military political regime in Myanmar was the reason why Western governments imposed sanctions on Myanmar. Western donors avoided channeling any aid to the government or its agencies, but instead provided limited support to NGOs and opposition groups. The primary form of aid at this time was humanitarian (Carr 2018). Western governments started taking the Myanmar military's liberalization rhetoric seriously after the formation of the Thein Sein government in 2011 and the subsequent political, legislative, and economic reforms. At this point, the approach to development cooperation in Myanmar shifted from one of decades of sanctions to one of conditional support (Taylor 2012; Décobert and 


\section{FDI}

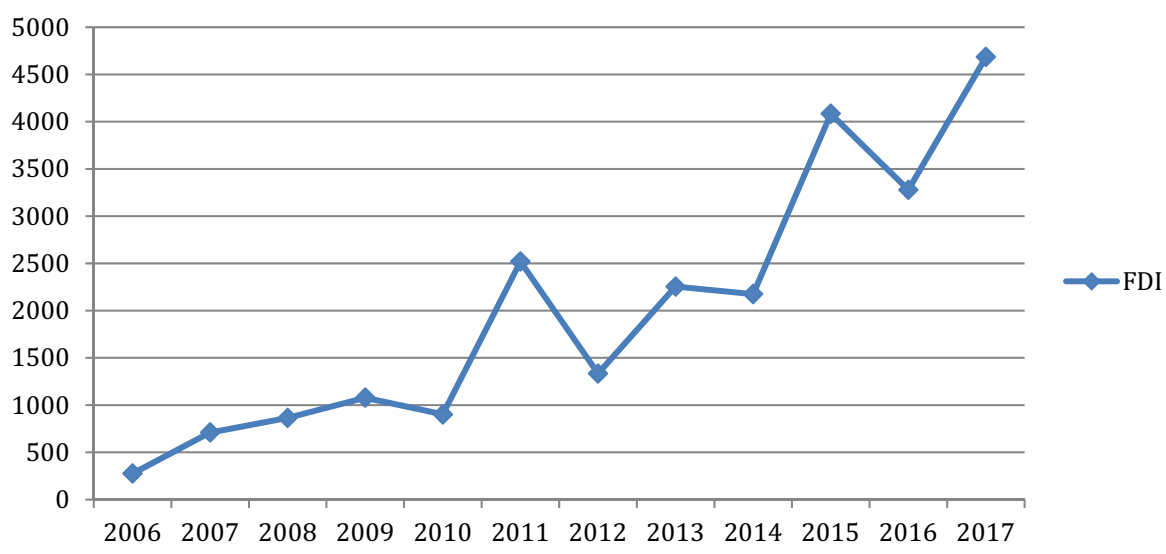

Fig. 3 Foreign direct investment to Myanmar 2006-2017. Source: Foreign Direct Investment to Myanmar, the World Bank and IMF

Wells 2020, and Nilsen 2020, in this special issue). The Thein Sein government actively looked for international support for its reform agenda, and aid agencies were quick to respond. Donors increasingly invested in the government, expecting their former beneficiaries to increase their engagement with the government as it became more legitimate. Myanmar soon became one of the world's largest recipients of aid, and the range of activities was wide, encompassing all sectors. A plethora of international organizations, development agencies, and NGOs have established themselves in Myanmar, increasing the need for coordination (Carr 2018). In the years before the 2015 election, official development assistance to Myanmar surged (see Fig. 2).

Private investors and businesses also saw opportunities as the country opened up. Although not as radical a change as with official development assistance, foreign direct investment in Myanmar gradually increased as the country liberalized. As can be seen in Fig. 3, it is not as sensitive to sways in public opinion of Myanmar as the official development assistance is, and has seen a more continuous increase. As Farrelly and Win (2016) put it: "Myanmar's shift from entrenched military regime to a system of dynamic and heavily contested, albeit fragile, political reform has created a bounty of new opportunities. In almost every sector of the economy, and in most spheres of life, Myanmar people are accepting foreign ideas and investment" (pp. 44-45). Bächtold has labelled it "the gold rush" (Bächtold 2015). The history of Western sanctions may have influenced the mode of capitalist development in Myanmar. Jones (2014b) argues that it drove the state to accept exploitative forms of foreign investment (see also Bächtold et al. 2020 and Schneider et al. 2020, in this special issue). The legacy of military rule also means that social movements, including the labor movement are weakly organized, to the extent that they have been able to mobilize. Due to the authoritarian legacy some local movements have moved abroad to neighboring countries such as Thailand. It remains to be seen what role 
this "activist diaspora" will play in the political development of Myanmar (Adam 2013).

The Western stance towards preliberalization Myanmar also affected Myanmar's development in other ways: it opened the doors for other collaborations to take shape. China was the first country to recognize the new regime in 1988 and has invested in Myanmar ever since. When most other donors were pulling out, China provided grants, subsidized loans, and debt relief (Carr 2018). China remains one of Myanmar's most important economic partners. One of the Myanmar government's strategies for economic growth is the establishment of the special economic zones (SEZs). Myanmar has looked to China, who successfully introduced SEZs to be able to experiment with economic reforms in a controlled and gradual manner. The establishment of these zones is thus a part of the country's big liberalization plan, where the economic plan included attracting foreign direct investment on a larger scale (Khandelwal and Teachout 2016). Bolesta claims that Myanmar has more in common with China than with its new Western partners and that, as a geographical neighbor and postsocialist economy, Myanmar is likely to follow China's trajectory and model of economic development. This includes the targeting of a number of industrial sectors for development and the establishment of special zones (Bolesta 2018; Hardaker 2020, in this special issue).

Despite all the challenges that Myanmar faces, the international aid industry is focusing on even progress and a gradual transition. Bächtold (2015) attributes this to an increasing bureaucratization and managerialization of the aid industry, measuring short-term results in project form and advocating stability above rapid social change, effectively depoliticizing development (cf. Ferguson 1990).

Some cooperation partners have avoided working in the unpredictable and dangerous conflict zones, and this remains a major challenge (Carr 2018). Many of the factors that contribute to conflict are also development related; for instance, the issue of land rights is central to poverty alleviation and to building sustainable livelihoods for ethnic communities (Kramer 2015). Land insecurity is a widespread problem in Myanmar as a whole, but women often hold weaker legal claims than men, also in customary law. For instance, it is standard practice to list men as heads of household, meaning that names on land user certificates tend to be male. Widows are particularly vulnerable under such a regime (Faxon et al. 2015).

The development sector in Myanmar has been highly dependent on the sways in Western approaches to political development in the country, whereas foreign investment has been more predictable. As investments increase, the priorities of aid donors and of foreign investors gain increasing influence over Myanmar politics as well as over the life and wellbeing of the Myanmar population.

\section{Development Challenges in Myanmar}

The importance of acknowledging the interaction between political development and the politics of development to fully understand and tackle the various development challenges that the people of Myanmar face is demonstrated by the articles in this special issue, each of them focusing on different aspects of development. 
An overarching development challenge for Myanmar is the prospect for sustainable development alongside economic growth. The article by Schneider et al. (2020, in this special issue) focuses on the multifaceted and simultaneous transitions that the international development community would like to see Myanmar undertake: a democratic and an economic transition, as well as a transformation of its development trajectory into a more sustainable one. In 2015, the same year that Myanmar elected a new civilian government, it also endorsed the 2030 agenda and the SDGs. However, different development goals do not always go hand in hand, and sustainable development in terms of ecosystem services can decline while human wellbeing increases. The article studies recent land use transitions and the collaboration between government, the private sector, and civil society and the potential that is left for sustainable development after the government transition (Schneider et al. 2020, in this special issue).

The theme that development is a complex process is evident also in the case of humanitarian aid. For providers of humanitarian aid, there is often a trade-off between the short-time goal of getting access to the most relevant areas and parts of the population as soon as disaster strikes and the more long-term goal of working to improve human rights in an authoritarian country. Nilsen (2020, in this special issue) points out that, to gain access to certain areas, aid providers may need to collaborate with the regime that is responsible for the suffering in the first place. In a country like Myanmar, where organizations have a difficult time interpreting the political development and what it implies for their relationship to state actors, they respond differently to this dilemma. Some organizations are idealist, in the sense that they push for human rights and seek to hold responsible actors accountable, whereas others see a need to work pragmatically with the government. Although this division of labor is not coordinated or intended, Nilsen demonstrates how it leads to a de facto multifaceted approach which balances humanitarian aid with more longterm human rights based approaches (Nilsen 2020, in this special issue).

Other efforts at collaboration are more intentionally coordinated, such as the multi-stakeholder platforms initiated by the NLD government to deal with land conflicts in the ethnic minority areas of Myanmar. When the NLD came to power, the involvement of international development actors increased and brought about ideas and discourses about inclusion and empowerment. Bächtold, Bastide, and Lundsgaard-Hansen (2020, in this special issue) analyze a multistakeholder platform that gathers regional governments, civil society organizations, private companies, and political ethnically based organizations around the same table to resolve land conflicts by collectively compiling data and updating maps. In the complex environment in which it operates, however, the multi-stakeholder platform effectively reduces the authority of ethnic political organizations while strengthening the central state (Bächtold et al. 2020, in this special issue).

New land legislation and international development projects may thus contribute to exacerbating rather than alleviating existing inequalities and the expansion of state-led and donor-supported development initiatives may strengthen state control in conflict affected areas. Hedström and Olivius (2020, in this special issue) focus on how these development processes intersect with existing gendered relations of power, disproportionately affecting women and increasing gendered insecurities. 
Women's access to formal land rights is severely restricted. Women are also overrepresented in the informal economy and have the primary responsibility for social reproduction. Large scale development projects that transform the economy without investing in social provisioning thus risk increasing gendered insecurity (Hedström and Olivius 2020, in this special issue).

The construction of special economic zones constitutes an example of ongoing government experiments with economic reforms. Hardaker (2020, in this special issue) conducts a case study of one such zone and concludes that it may have some intended consequences, such as increased foreign direct investment, job creation, transfer of knowledge, and strengthening of the industrial infrastructure. However, there is a risk that the jobs created will be low quality and low pay. Importantly, the special economic zone is not sufficiently embedded in its surroundings-workers have long commutes, local supplier networks are not used, and local businesses do not profit from the zone. In the short term, then, these economic reforms will have limited impacts on the living standards of the population in the area (Hardaker 2020, in this special issue).

One solution to reduce inequalities, when economic reforms fail to do so, could be the increased political representation of various groups to redress past injustices and promote peace. While the ethnic diversity of Myanmar has been reflected in the number of ethnic parties standing for election, they have not been as successful in winning seats in the legislature. At the time of the 2015 election, many democracy promotion initiatives saw support of the NLD as synonymous with supporting democratization. However, the landslide victory of the NLD in the 2015 election came at the expense of the representation of ethnic parties. Tan and Preece (2020, in this special issue) assess the prospects of small ethnic parties in the Myanmar plurality-rule electoral system. They conclude that ethnic parties can win seats if there is a coordinated merging of parties in ethnically concentrated constituencies. The likelihood of ethnic parties merging with the nation-wide parties NLD or USDP decreases as disappointment with their inaction on ethnic issues increases (Tan and Preece 2020, in this special issue). With donor support of the NLD wavering, a window of opportunity for ethnic parties to reap the benefits of democracy support projects may open.

When democracy support focuses primarily on supporting the formal political process - the holding of free and fair elections and party organization support - there is a risk that the long-term process of fostering democratic and egalitarian values is overseen. The implications of Myanmar's return to civilian rule are put under scrutiny and questioned by Htun and Jensenius (2020, in this special issue), demonstrating various challenges ahead. They build on recent survey data demonstrating that anti-democratic views continue to be widespread. This is problematic not just for the prospects of democratic consolidation per se but also because such conservative attitudes are linked to nationalist and gender unequal attitudes (Htun and Jensenius 2020, in this issue). In the short run, the introduction of competitive elections and a woman front figure in Aung San Suu Kyi are not guarantees for either a democratic or gender equal developmentparticularly not in the absence of a growing civic culture (Almond and Verba 1963).

Taken together, the contributions to this special issue focus on a number of different development challenges: sustainable development, humanitarian aid, land conflicts, gendered insecurities, economic development, the political representation of ethnic minorities, and values and norm systems. Regardless of the development challenge 
they tackle, they all demonstrate the various ways in which political development interact with the politics of development.

\section{Conclusions}

This special issue on development challenges in Myanmar highlights two distinct but interconnected themes: political development and the politics of development. The political development of Myanmar has served as a starting point for many analyses and predictions about the country's political future. Political development in a seemingly democratic direction made Myanmar the focus of the international democracy promotion regime-governmental and nongovernmental organizations seeking to promote democracy. Although democracy is a multifaceted concept, elections are seen as the bedrock of democracy. When a former autocracy decides to not just hold multiparty elections but also seems determined to ensure the integrity and quality of such elections, an enormous amount of election support is mobilized (Donno 2013; Carothers 2007; Norris et al. 2014). An actual transfer of power, coupled with relatively high quality of the elections, as in Myanmar 2015, sends strong symbolic signals to the donor community that democracy promotion is relevant and that development assistance is justified. Although these signals are strong, they may be simplified. While the holding of elections may be necessary for democracy to develop, it is far from sufficient.

In Myanmar, the holding of elections coexisted with guarantees for the military's continued grip on power and with widespread antidemocratic attitudes in the population, including hostile views on ethnic minorities and gender unequal attitudes. It takes a long time to develop an understanding and appreciation of what democracy can and cannot bring about, and even longer for stable democratic norms to develop in a citizenry. When the expression of democratic devotion is intimately connected with access to donor funds, it is difficult to assess how genuine, deep, and widespread domestic support for democracy really is.

It only took an election to draw donors and democracy promotion organizations to Myanmar, but when contradictory and very strong symbolic signals were sent out about atrocities such as ethnic cleansing, many were quick to leave or downscale. The challenges to development remain, however, and are persistent and require consistency and maybe even patience. At the moment, the persistence of foreign direct investment is more evident than the persistence of democracy promotion. This special issue addresses many of those issues that are at stake for the future development of Myanmar in the 2020 elections and beyond: a truly democratic constitution, political representation of ethnic groups and women, the balance between state-building and incorporation of the local, long-term sustainable development alongside economic reforms and social provisioning, and continued security concerns.

Acknowledgements This work was supported by the Swedish Research Council. I would also like to thank EADI and the Uppsala Forum for Democracy, Peace and Justice for support. In addition Joakim Kreutz, Flora Hajdu, Sara Bondesson, the Uppsala Development Studies seminar, the participants of the 
Uppsala Workshop on Development Challenges in Myanmar and anonymous reviewers provided useful feedback on this article as well as on the special issue that it serves to introduce.

Open Access This article is licensed under a Creative Commons Attribution 4.0 International License, which permits use, sharing, adaptation, distribution and reproduction in any medium or format, as long as you give appropriate credit to the original author(s) and the source, provide a link to the Creative Commons licence, and indicate if changes were made. The images or other third party material in this article are included in the article's Creative Commons licence, unless indicated otherwise in a credit line to the material. If material is not included in the article's Creative Commons licence and your intended use is not permitted by statutory regulation or exceeds the permitted use, you will need to obtain permission directly from the copyright holder. To view a copy of this licence, visit http://creativecommons.org/licen ses/by/4.0/.

\section{References}

Adam, S. 2013. Challenging Hydropower Development in Myanmar (Burma): Cross-Border Activism under a Regime in Transition. The Pacific Review 26 (2): 129-152.

Agatha Ma, Poe Ei Phyu, and Catriona Knapman. 2018. In the Land of Wise Old Men: Experiences of Young Women Activists in Myanmar. Gender and Development 26 (3): 459-476.

Almond, Gabriel A., and Sidney Verba. 1963. The Civic Culture: Political Attitudes and Democray in Five Nations. Princeton: Princeton University Press.

Bächtold, Stefan. 2015. The rise of an anti-politics machinery: peace, civil society and the focus on results in Myanmar. Third World Quarterly 36 (10): 1968-1983.

Bächtold, Stefan, Joan Bastide and Lara Lundsgaard Hansen. 2020. Assembling drones, activists, and oil palm: Implications of a mutli-stakeholder land platform for state formation in Myanmar. European Journal of Development Research. In this issue.

Barrow, Amy. 2015. Contested Spaces during Transition: Regime Change in Myanmar and its Implications for Women. Cardozo J Law \& Gender 22: 75-108.

Bexell, Magdalena, and Kristina Jönsson. 2017. Responsibility and the United Nations' Sustainable Development Goals. Forum for Development Studies 44 (1): 13-29.

Bjarnegård, Elin. 2017. The Unequal Peace. In Debating the East Asian Peace, ed. Elin Bjarnegård and Joakim Kreutz. Copenhagen: NIAS Press.

Bolesta, Andrzej. 2018. Myanmar-China Peculiar Relationship: Trade, Investment and the Model of Development. Journal of International Studies 11 (2): 23-36.

Brown, Stephen. 2005. Foreign Aid and Democracy Promotion: Lessons from Africa. European Journal of Development Research 17 (2): 179-198.

Bünte, Marco. 2009. The Politics of Reguees in and outside Burma/Myanmar. Journal of Current Southeast Asian Affairs 28 (2): 3-5.

Bush, Sarah Sunn. 2015. The Taming of Democracy Assistance. Why Democracy Promotion Does Not Confront Dictators. Cambridge: Cambridge University Press.

Carothers, Thomas. 2006. The Backlash against Democracy Promotion. Foreign Affairs 85 (2): 55-68.

Carothers, Thomas. 2007. The "Sequencing" Fallacy. Journal of Democracy 18 (1): 12-27.

Carothers, Thomas. 2016. Democracy Support Strategies: Leading with Women's Empowerment. Washington, D.C: Carnegie Endowment for International Peace.

Carr, Thomas. 2018. Supporting the Transition. Understanding Aid to Myanmar since 2011. San Francisco: Asia Foundation.

Carter Center. 2015. Observing Myanmar's 2015 General Elections. Final Report. Atlanta: The Carter Center.

Cheesman, Nick. 2014. What Does the Rule of Law Have to Do with Democratization (in Myanmar)? South East Asia Research 22 (2): 213-232.

Cheesman, Nick. 2017. How in Myanmar "National Races" Came to Surpass Citizenship and Exclude Rohingya. Journal of Contemporary Asia 47 (3): 461-483.

Coetzee, Wayne, and Fredrik Söderbaum. 2016. Nordic Development Studies: Lessons, Pitfalls and Future Directions. Strategic Review for Southern Africa. 38: 1. 
Croissant, Aurel, and Jil Kamerling. 2013. Why Do Military Regimes Institutionalize? Constitutionmaking and Elections as Political Survival Strategy in Myanmar. Asian Journal of Political Science 21 (2): 105-125.

Décobert, Anne and Tamas Wells. 2020. Interpretive complexity and crisis: the history of international aid to Myanmar. European Journal of Development Research. In this issue.

Diamond, Larry. 2002. Thinking About Hybrid Regimes. Journal of Democracy 13: 21-35.

Donno, Daniela. 2013. Defending Democratic Norms: International Actors and the Politics of Electoral Misconduct. Oxford: Oxford University Press.

Egreteau, Renaud. 2016. Caretaking Democratization. The Military and Political change in Myanmar. London: Hurst \& Company.

Eriksson Baaz, Maria. 2005. The Paternalism of Partnership: A Postcolonial Reading of Identity in Development Aid. London: Zed Books.

EU EOM. 2015. EU EOM Myanmar General Elections 2015. Final Report. Brussels: EU Election Observation Mission.

Farrelly, Nicholas, and Chit Win. 2016. Inside Myanmar's Turbulent Transformation. Asia and the Pacific Policy Studies 3 (1): 38-47.

Faxon, Hilary, Roisin Furling, and May Sabe Phyu. 2015. Reinvigorating Resilience: Violence against Women, Land Rights, and the Women's Peace Movement in Myanmar. Gender \& Development 23 (3): 463-479.

Ferguson, James. 1990. The Anti-Politics Machine. "Development", depoliticization, and bureaucratic power in Lesotho. Cambridge: Cambridge University Press.

Finkel, Steven, Aníbal Pérez-Liñán, and Mitchell Seligson. 2007. The Effects of U.S: Foreign Assistance on Democracy Building 1990-2003. World Politics 59 (3): 404-439.

Fukuda-Parr, Sakiko, Alicia Ely Yamin, and Joshua Greenstein. 2014. The Power of Numbers: A Critical Review of Millennium Development Goal Targets for Human Development and Human Rights. Journal of Human Development and Capabilities 15 (2-3): 105-117.

Fukuda-Parr, Sakiko. 2016. From the Millennium Development Goals to the Sustainable Development Goals: Shifts in Purpose, Concept, and Politics of Global Goal Setting for Development. Gender \& Development 24 (1): 43-52.

Geha, Carmen. 2019. The Myth of Women's Political Empowerment within Lebanon's Sectarian PowerSharing System. Journal of Women, Politics \& Policy 40 (4): 498-521.

GEN. 2017. Gender \& Politics in Myanmar. Women and Men Candidates in the 2015 Election. Yangon: Gender Equality Network.

Hadenius, Axel, and Jan Teorell. 2007. Pathways from Authoritarianism. Journal of Democracy 18: 143-157.

Harcourt, Wendy. 2005. The Millennium Development Goals: A Missed Opportunity? Development 48: 1-4.

Hardaker, Sina. 2020. Embedded enclaves? Initial implications of the development of special economic zones in Myanmar. European Journal of Development Research. In this issue.

Hedström, Jenny. 2013. Where are the Women? Negotiations for Peace in Burma. Stockholm: The Swedish Burma Committee.

Hedström, Jenny. 2016. We Did Not Realize about the Gender Issues. So, We Thought It Was a Good Idea. International Feminist Journal of Politics 18 (1): 61-79.

Hedström, Jenny and Elisabeth Olivius. 2020. Insecurity, Dispossession, Depletion: Women's Experiences of Power-War Development in Myanmar. European Journal of Development Research. In this issue.

Hirschi, Eva. 2018. Bringing the land use policy to life. Frontier Myanmar. Published Wednesday, November 7, 2018. Accessed on May 14, 2019: https://frontiermyanmar.net/en/bringing-the-landuse-policy-to-life.

Huang, Roger Lee. 2013. Re-Thinking Myanmar's Political Regime: Military Rule in Myanmar and Implications for Current Reforms. Contemporary Politics 19 (3): 247-261.

Huang, Roger Lee. 2017. Myanmar's Way to Democracy and the Limits of the 2015 Elections. Asian Journal of Political Science 25 (1): 25-44.

Htun, Mala and Francesca Jensenius. 2020. Political Change, Women's Rights and Public Opinion on Gender Equality in Myanmar. European Journal of Development Research. In this issue.

Jones, Lee. 2014a. Explaining Myanmar's Regime Transition: The Periphery is Central. Democratization 21 (5): 780-802. 
Jones, Lee. 2014b. The Political Economy of Myanmar's Transition. Journal of Contemporary Asia 44 (1): $144-170$.

Khandelwal, Amit K. and Teachout, Matthieu. 2016. Special Economic Zones for Myanmar. International Growth Center Policy Note.

Kramer, Tom. 2015. Ethnic Conflict and Lands Rights in Myanmar. Social Research: An International Quarterly 82 (2): 355-374.

Latt, Shwe Shwe Sein, Kim N.B. Ninh, Mi Ki Kyaw Myint, and Susan Lee. 2017. Women's Political Participation in Myanmar: Experiences of Women Parliamentarians 2011-2016. Yangon: The Asia Foundation and Phan Tee Eain.

Mac Ginty, Roger. 2012. Routine Peace: Technocracy and Peacebuilding. Cooperation and Conflict 47 (3): 287-308.

Ma Khin Mar Mar Kyi (2014) In Nick Cheeseman, Nicholas Farrelly and Trevor Wilson Simpson (eds) Debating Democratization in Myanmar. Singapore: ISEAS

Nilsen, Marte and Stein Tønnesson. 2014. High Risk of Electoral Violence in Myanmar. PRIO Policy Brief. Oslo: Peace Research Institute Oslo (PRIO).

Nilsen, Marte. 2020. Perceptions of Rights and the Politics of Humanitarian Aid in Myanmar. European Journal of Development Research. In this issue.

Norris, Pippa, Richard W. Frank, and Ferran Martínez i Coma. 2014. Advancing Electoral Integrity. Oxford: Oxford University Press.

Razavi, Shahra. 2016. The 2030 Agenda: Challenges of Implementation to Attain Gender Equality and Women's Rights. Gender and Development 24 (1): 25-41.

Savun, Burcu, and Daniel C. Tirone. 2011. Foreign Aid, Democratization, and Civil Conflict: How Does Democracy Aid Affect Civil Conflict? American Journal of Political Science 55 (2): 233-246.

Schedler, Andreas. 2006. Electoral Authoritarianism: The Dynamics of Unfree Competition. Boulder, CO: Lynne Rienner Publishers.

Schneider, Flurina, Mélanie Feurer, Lara Maria Lundsgaard-Hansen, Win Myint, Cing Don Nuam, Katharaina Nydegger, Christoph Oberlack, Nwe New Tun, Aung Myin Tun, Julie Zähringer, Peter Messerli. 2020. Sustainable Development under Competing Claims on Land: Three Pathways between Land Use Changes, Ecosystem Services and Human Well-Being. European Journal of Development Research. In this issue.

Scholte, Jan Aart, and Fredrik Söderbaum. 2017. A Changing Global Development Agenda? Forum for Development Studies 44 (1): 1-2.

Scott, James M., and Carie A. Steele. 2011. Sponsoring Democracy: The United States and Democracy Aid to the Developing World. International Studies Quarterly 55 (1): 47-69.

Sen, Amartya. 1999. Development as Freedom. Oxford: Oxford University Press.

Seng Maw Lahpai. 2014. State Terrorism and International Compliance: The Kachin Armed Struggle for Political Self-Determination. In Cheeseman, Nick, Nicholas Farrelly and Trevor Wilson (eds.), Debating Democratization in Myanmar. Singapore: ISEAS

SiuSue Mark. 2016. Are the Odds of Justice "Stacked" against Them? Challenges and Opportunities for Securing Land Claims by Smallholder Farmers in Myanmar. Critical Asian Studies 48 (3): 443-460.

Skagerlind, Helena Hede. 2019. Governing Development. The Millenium Development Goals and Gender Policy Change in Sub-Saharan Africa. Doctoral Thesis in Political Science at Stockholm University.

Slater, Dan. 2014. The Elements of Surprise: Assessing Burma's Double-Edged Détente. South East Asian Research 22 (2): 171-182.

Smith, Jeffrey. 2018. How the UN's Sustainable Development Goals undermine democracy. Quartz Africa. June 7, 2018. Accessed on https://qz.com/africa/1299149/.

South, Ashley. 2018. "Hybrid Governance" and the Politics of Legitimacy in the Myanmar Peace Process. Journal of Contemporary Asia 48 (1): 50-66.

Stokke, Kristian, Khine Win, and Soe Myint Aung. 2015. Political Parties and Popular Representation in Myanmar's Democratisation Process. Journal of Current Southeast Asian Affairs 34 (3): 3-35.

Stokke, Kristian and Soe Myint Aung. 2020. Transition to democracy or hybrid regime? The dynamics and outcomes of democratization in Myanmar. European Journal of Development Research. In this issue.

Tan, Netina and Cassandra Preece. 2020. Electoral System, Ethnic Parties and Party System Stability in Myanmar. European Journal of Development Research. In this issue.

Taylor, Robert H. 2012. Myanmar: From Army Rule to Constitutional Rule? Asian Affairs 43 (2): 221-236. 
Thawnghmung, Ardeth. 2016. The Myanmar Elections 2015: Why the National League for Democracy Won a Landslide Victory. Critical Asian Studies 48 (1): 132-142.

WLB. 2014. If they had hope, they would speak. Chiang mai: Women's League of Burma.

Wright, Joseph. 2009. How Foreign Aid Can Foster Democratization in Authoritarian Regimes. American Journal of Political Science 53 (3): 552-571.

Publisher's Note Springer Nature remains neutral with regard to jurisdictional claims in published maps and institutional affiliations. 